\title{
Rhythmic change in the medieval octosyllable and the development of group stress
}

\author{
T. M. Rainsford \\ Department of Linguistics, University of Cambridge \\ tmr740-ac@yahoo.co.uk
}

\section{Introduction ${ }^{1}$}

One of the most puzzling questions in the history of French is why a language which historically showed strong lexical stress should have evolved a 'group stress' system, in which stress is determined by syntactic structure. Aside from some rather general accounts (e.g. Kukenheim 1971, Banniard 1998), little has been written on this change, and virtually nothing on its chronology or causes. In this paper, I will argue that the chronology of this change can be shown by studying the rhythm of medieval syllabic verse. In particular, I will argue that medieval versification shows that rhythmic organization based on stress becomes progressively less important to speakers, and will suggest that this is a consequence of an emerging 'deafness' (in the sense of Dupoux et al. 1997) to stress contrasts in the language as a whole.

I begin by giving some background information on stress, its role in Modern French and medieval versification, and outline a methodology for its reconstruction (§2). In $\S 3$, I present a study of rhythmic reconstructions of octosyllabic texts, showing that there is a clear evolution that may vary in chronology according to text type. The significance of these findings is considered in $\S 4$.

\section{Background}

This section presents an overview of three areas of study crucial to the interpretation and understanding of the results in section three. I begin with a brief examination of the evolution and perception of stress in French $(\$ 2.1)$ to demonstrate both the form and an important consequence of the prosodic change under investigation. I then consider previous work on the rhythm of the octosyllable (\$2.2), which provides the starting point for my own study. Finally, I detail the methodology used to reconstruct the rhythm of medieval texts in the study $(\$ 2.3)$.

\subsection{Stress in French}

\subsubsection{Change in the stress system}

It is clear from the phonological development of French that Gallo-Romance lexemes had fixed primary and secondary lexical stress. Hence, the sound laws of the Neogrammarians describing the evolution of the vowel system show different developments for vowels in initial, primary stressed (tonic) and unstressed position : witness, for instance, the differing fates of the three /e/'s in Lat. DEBEERE $>$ OFr. deveir ${ }^{2}$. Such laws apply to individual words, suggesting that lexical stress patterns were essentially unchanged in the context of the phonological phrase. ${ }^{3}$

The same is not true of modern French. Analyses of stress in modern French ${ }^{4}$ are all based on stress groups (groupes accentuels), two or three lexemes which carry a single primary stress on the final syllable. These groups are syntactically defined and although the precise definition varies from model to model, in general nouns, verbs and adjectives form the right boundary of a stress group, and are grouped with preceding function words. Pre-nominal adjectives usually fall in the same stress group as the following noun; nouns may fall into the same stress group as following adjectives. Thus, a modern French 
NP such as la belle fille bears only one main stress, on the noun fille; while at an earlier stage of the language, stress would also have fallen on the adjective belle. ${ }^{5}$

The change to group stress was complete by the time the first metalinguistic texts are found in C16, while it is assumed that lexical stress rules still applied in the earliest French texts. Thus, it is in the medieval period that evidence for this change is to be sought.

\subsection{2 'Stress deafness' in Modern French}

One of the consequences of a system in which stress position is entirely predictable from syntactic structure is that modern French speakers do not acquire a phonological distinction between stressed and unstressed syllables. This is attested in several studies by Dupoux and Peperkamp (Dupoux et al. 1997; Dupoux, Peperkamp and Sebastián-Gallés 2001; Dupoux et al. 2008). When asked to disambiguate minimal pairs of non-words distinguished only by stress placement (e.g. numi vs. numi), L1 French speakers perform significantly worse than L1 Spanish speakers, for whom stress placement is phonemic. French speakers and Spanish speakers perform equally well in a control task where the minimal pairs are distinguished by a phonemic contrast present in both languages (e.g. fiku vs. fitu) (Dupoux et al. 1997). A follow-up study (Dupoux et al. 2008) showed that even French learners of Spanish as an L2 found difficulty in perceiving stress-contrasted minimal pairs. The finding was repeated when the minimal pair was made up of a real Spanish word and a non-word (e.g. gorro 'hat' vs. gorro), from which the authors conclude that French L1 speakers lack the ability to store stress position in their mental lexical representations.

This 'stress deafness' effect is observed to a lesser extent in other languages with regular stress positioning, namely Finnish and Hungarian (Peperkamp and Dupoux 2002), but in French it is particularly strong. Dupoux and Peperkamp (2002) suggest that as the stress position in French corresponds simply to a phonological phrase boundary, acquirers will not include stress as part of the prelexical representation of speech that forms the input to lexical acquisition. In contrast, although Old French did not contain stress contrasted minimal pairs, it is unlikely that speakers exhibited 'stress deafness'. Old French stress was not oxytonic, as it could fall on the penultimate syllable if the final syllable were schwa (e.g. /'par.lə/ 'speaks' vs. /par.'læ/ 'spoke'). Consequently, the regularity of the stress rule was only discernable to learners who had acquired the distinction between full vowels and schwa. Moreover, until a certain point the language contained unstressed enclitic pronouns. Final stressed $[\varnothing]$ in Modern French dis-le derives from an historical schwa that has been fronted and rounded, not a tonic or even pretonic development of Latin [o] from ILLUM. Both of these features complicate the surface form of the stress rule, and make speakers less likely to exhibit stress deafness (Dupoux and Peperkamp 2002, Peperkamp 2004).

\subsection{Stress and the octosyllable}

Traditionally, medieval French versification is considered purely syllabic. Example (1) is a typical octosyllabic extract:

(1) Nagaires, chevauchant, pensoye

Com home triste et doloreux,

Au dueil ou il fault que je soye

Le plus dolent des amoureux [.]

(Alain Chartier, La Belle Dame sans mercy, 11. 1-4)

For the purposes of demonstration, I have underlined the stressed syllables in the extract based simply on intuition. Note that as in all octosyllabic texts, the syllable at the rime (the final non-schwa syllable) is always stressed, but within the rest of the line there is no consistent organization of stressed syllables. Indeed, this has led some observers such as Lote to argue that all line-internal syllables are unstressed : 
The position that all line-internal syllables are unstressed seems overstated : while they may be less prominent than the rime syllable, it seems very unlikely that there are no stresses in a sequence of seven syllables. A number of studies (Klausenburger 1970 ; Le Mée 1978 ; Guthrie 1987 ; Pensom 2000) have undertaken to investigate the organization of these line-internal stresses, and in particular to demonstrate that older texts show an iambic (weak-strong) rhythm. Noyer (2002) tests a substantial corpus of octosyllabic texts from 1000 to 1180 for conformity to a fairly permissive iambic meter, such as is found in the English poetic tradition from Chaucer in C14. Two striking findings emerge from the study. Firstly, the proportion of lines per text that conform to the constraints of an iambic meter range from 54\% to $93 \%$, figures well in excess of chance (41\%, estimated from a prose control) (2002: 136). Secondly, older (pre-1130) texts show a much higher proportion of iambic lines, and a significant correlation is shown between date of composition of text and iambicity (2002:137). While the paper falls short of demonstrating that the meter of Old French texts was iambic in the same way as in the English tradition, it presents clear evidence for a change in the rhythm of the octosyllable during the Old French period, a change which may not have run to completion by the end point of Noyer's study in 1180 . In his conclusion, Noyer draws a speculative link between the decline in iambicity and the loss of lexical stress in the language as a whole (2002:160-1).

This paper follows on from such work on versification by carrying out a more wide-ranging investigation of the rhythmic patterns of medieval French verse, covering a longer time period and looking beyond iambicity for evidence of any rhythmic organization. The wider goal remains to interpret any findings in the light of the emergence of group stress in French, and I will address this in the conclusion.

\subsection{Rhythmic reconstruction}

As stress is never directly marked in medieval French texts, the position of stressed syllables must be reconstructed. Fortunately, the changes in stress assignment occurring over the medieval period did not affect the position of the primary stressed syllable within the word, only the rules governing the realization or non-realization of stress. Where realized, non-emphatic stress in both modern French and Old French falls on the final non-schwa syllable of a word. Consequently, the starting point of the reconstruction is to distinguish three types of syllables based on their likelihood of being stressed :

Type 0: All schwa syllables (e.g. Marie, demander)

Type 1: Pretonic syllables of a polysyllable; some (mainly functional) monosyllables (e.g. Marie, demander, et)

Type 2: Tonic syllables of a polysyllable; most monosyllables (e.g. Marie, demander, roi)

Examples (2-4) show this syllable numbering applied to three (non-consecutive) lines from Chartier's $L a$ Belle Dame sans mercy:

(2) $\quad \begin{array}{lllllllll}0 & 2 & 1 & 2 & 1 & 2 & 0 & 2(0)\end{array}$

je vueil laissier aux autres faire

(3) $\quad \begin{array}{llllllll}1 & 2 & 0 & 0 & 2 & 0 & 0 & 2\end{array}$

et gaires de bruit ne menoit

(4) $\quad \begin{array}{lllllllll}2 & 0 & 2 & 2 & 2 & 2 & 0 & 2 & 0\end{array}$

car de plus beaulx jeux on se lasse

This syllable typology does not represent the rhythm of the line. It merely labels syllables according to their likelihood of being stressed. Schwa syllables ${ }^{7}$ are very unlikely to be prominent, so are labelled as type 0 . However, the final full vowel of a word, historically the location of primary stress, is labelled as type 2 to show that I consider it very likely to have been prominent. Based on this 'likelihood of stress' 
typology I then aim to reconstruct the actual prominence pattern of a line of verse. It is not enough simply to say that all type 2 syllables are prominent. Example (4) shows a typical case of a succession of type 2 monosyllables. While each may have the potential to bear stress, a reconstruction positing four equal, adjacent stresses is implausible. Sequences such as this are virtually impossible to reconstruct in any principled way. To distinguish cases such as these from more straight-forward reconstructions such as in (2) and (3), the second stage of the reconstruction assigns prominence or non-prominence to a syllable based on the types of its neighbours : Prominence rule : Any syllable of a higher value type than its neighbours is
prominent $(\mathrm{P}) .^{8}$

Non-prominence rule : Any syllable of a lower value type than one of its neighbours is non-prominent (n).

Prominence is a relative concept, with a syllable reconstructed as 'prominent' because it is more likely to be stressed than its neighbours. In cases where neither the prominence nor the non-prominence rule applies, syllables are left unmarked ; they are considered 'possibly prominent'. Effectively, the reconstruction in these cases is only partial. Below the effect of applying these rules to examples (2-4) is shown :

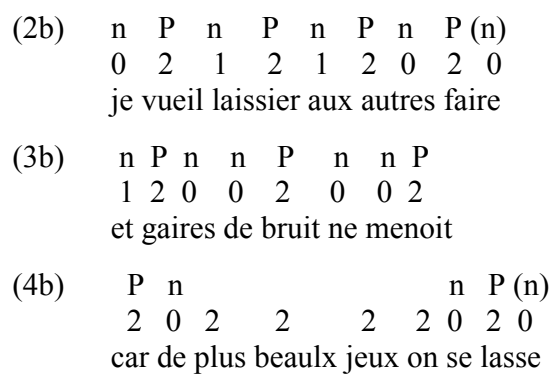

From these reconstructions, we can identify example (2) as iambic and example (3) as following a $2+3+3$ rhythm. The problematic sequence in example (4) is treated in the most principled way by leaving it unreconstructed. However, the partial reconstruction is still of use. Even with the middle section of the line unreconstructed, we can be sure that (4) does not show the same rhythmic pattern as (2) or (3), as the second syllable $d e$ is not prominent.

\section{Study: the rhythm of the octosyllable}

The study examines the rhythmic patterns of octosyllabic verse in a corpus of 500-line extracts drawn from the earliest texts to 1500 , using rhythmic reconstructions as outlined in $\S 2.3$. In addition to the focus on change over time, I will also consider whether there is a secondary effect of text type.

\subsection{Corpus}

The octosyllabic corpus used for this study is made up of twenty-seven 500-line extracts, divided into three sub-corpora $:^{9}$

Base : narrative texts, central dialect, 1175-1500 (10 extracts)

Theatre : religious and secular theatre ; mainly central dialects ; 1150-1500 (12 extracts)

Early : narrative texts pre-1175 (5 extracts)

The Base sub-corpus, containing narrative texts written in a central dialect, will form the core data to be analysed. It is intended as a control against which data from text types can be compared, both in this and in future studies. Because of the poverty of the philological record, it is not possible to extend the Base 
sub-corpus before 1175 without including non-central texts. However, it is clearly undesirable to exclude valuable data from earlier texts, and so these are included in a separate 'Early' sub-corpus.

The Theatre sub-corpus contains both religious and secular 'theatrical' texts. These are understood here to be texts with parts written for two or more interlocutors, and intended for spoken oral performance. Performed monologues (such as chansons de geste) and lyric dialogues (such as between amant et dame) are not included in this category. The contrast between narrative monologue and theatrical dialogue texts is designed to investigate whether any findings are affected by text type. It is possible that theatrical dialogues are more representative of the spoken language, as they are written for oral performance and contain interaction between characters. However, early narrative texts were also intended for oral performance, so this is not necessarily a valid assumption. The comparison between the two text types can be retained across the period of study.

Selected texts are drawn as far as possible from modern editions using a single base manuscript with limited editorial interventions. Texts are dated by approximate date of composition, not by the date of the base manuscript. Texts with a known geographical origin have been preferred. In general, I have tried to omit texts which cannot be dated to within 25 years, or which show extensive evidence of later reworking, unless the text is sufficiently unique to merit study despite uncertainty over precise dating or origin (e.g. Passion de Clermont). To ensure that any potential chronological developments could be clearly shown, a priority in text selection was to achieve an even distribution of extracts over the time period in each sub-corpus. A full list of corpus texts, abbreviations and editions is given in the References.

\subsection{Results}

I have elected to investigate the occurrence of six rhythmic patterns, focusing on the position of prominences on the four middle syllables of the octosyllabic line. These are detailed below in table 1 . Variation in the final two positions in the line may be disregarded, as the obligatory line-final stress means that the eighth syllable is always prominent. As a consequence, the seventh is nearly always nonprominent. Variation on the first two syllables of the line is certainly attested, but is not examined for the purposes of this study. ${ }^{10}$

Table 1: Rhythmic patterns

\begin{tabular}{|c|c|c|c|c|}
\hline \multirow{2}{*}{ Pattern } & \multicolumn{4}{|c|}{ Syllable } \\
\cline { 2 - 5 } & $\mathbf{3}$ & $\mathbf{4}$ & $\mathbf{5}$ & $\mathbf{6}$ \\
\hline$s 4+s 6$ & $\mathrm{n}$ & $\mathrm{P}$ & $\mathrm{n}$ & $\mathrm{P}$ \\
\hline$s 3+s 6$ & $\mathrm{P}$ & $\mathrm{n}$ & $\mathrm{n}$ & $\mathrm{P}$ \\
\hline$s 3+s 5$ & $\mathrm{P}$ & $\mathrm{n}$ & $\mathrm{P}$ & $\mathrm{n}$ \\
\hline s4only & $\mathrm{n}$ & $\mathrm{P}$ & $\mathrm{n}$ & $\mathrm{n}$ \\
\hline s5only & $\mathrm{n}$ & $\mathrm{n}$ & $\mathrm{P}$ & $\mathrm{n}$ \\
\hline s6only & $\mathrm{n}$ & $\mathrm{n}$ & $\mathrm{n}$ & $\mathrm{P}$ \\
\hline
\end{tabular}

The number of lines in each extract matching each pattern was counted. Exact correspondence of ' $n$ 's and 'P's was required. So, for example, (2) above would match pattern $s 4+s 6$ only (and not s4only or s6only), 
while (3) would match pattern s5only only. Partial reconstructions often match more than one pattern, but are weighted so as not to skew results. Consider example (5) :

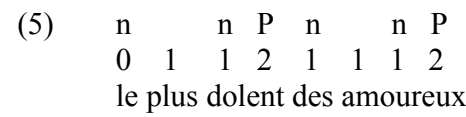

(BelleDame, 1. 4)

Syllable 6 in example (5) is not marked as ' $n$ 'or ' $P$ '. Consequently, the example will match both pattern s4only and pattern $s 4+s 6$. However, as the line has one unreconstructed position (' $n$ ' or 'P'), it counts only as a half towards the total matches to these patterns. In effect, the less complete a reconstruction, the more patterns it will match, but the less it will count towards the total for each pattern. An extreme case (see (4) above) with all four central positions unreconstructed will match all six patterns in table 1, but will only count for $0.5^{4}=0.0625$ towards each total.

Tables 2-4, included in the Appendix, show the frequency with which each pattern in Table 1 is attested for each text in the corpus. The figures in the following discussion are generated from this data. I begin with a simple illustration of how the data show significant differences between the rhythms of two sample texts (\$3.2.1). I then show the effect of chronology on rhythmic organization (\$3.2.2), and finally suggest that rhythmic organization may have varied between narrative and theatrical texts (\$3.2.3).

\subsubsection{Two types of text}

Figure 1 below shows rhythmic patterns attested in the Thebes and BelleDame extracts.

Figure 1: Rhythmic patterns attested in Thebes and BelleDame

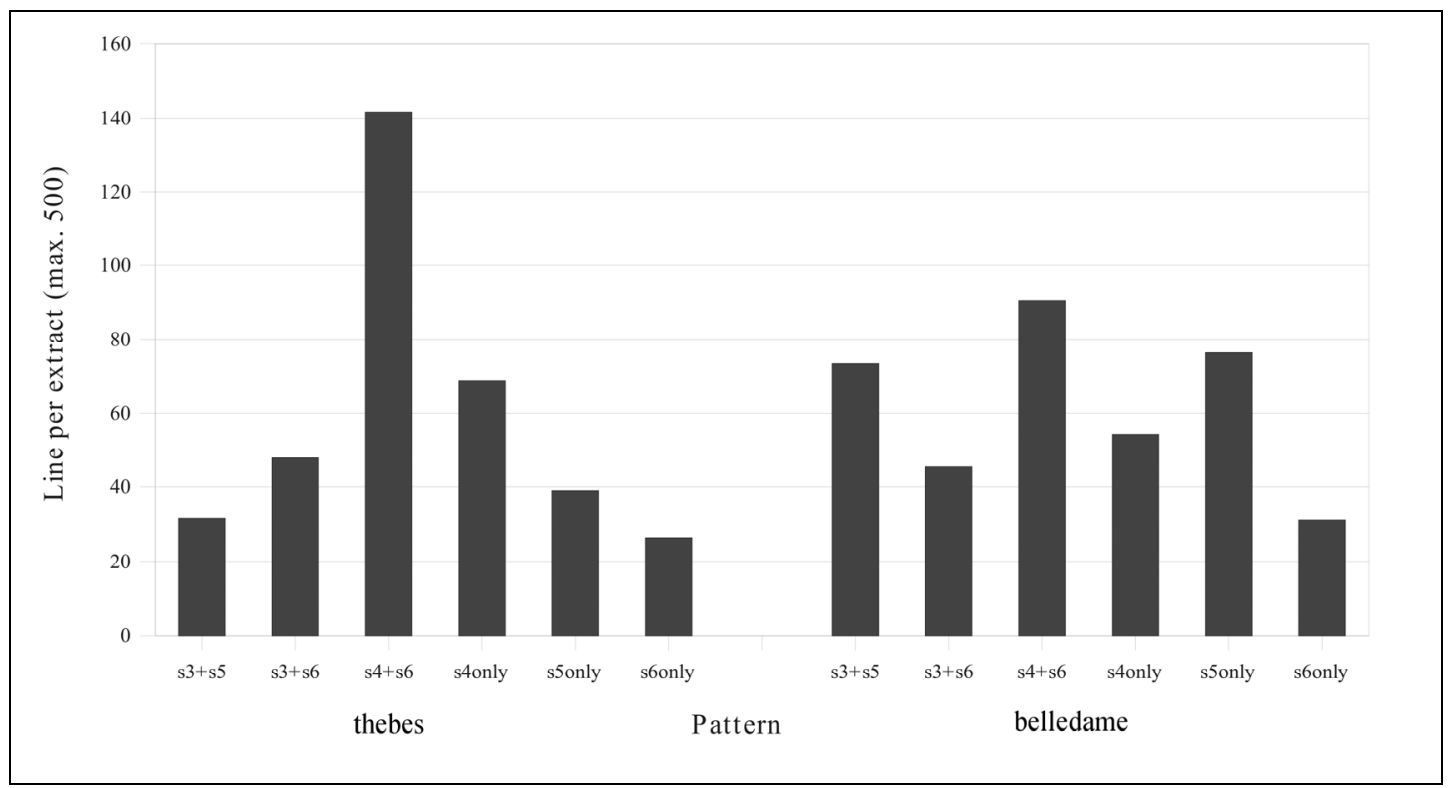

Instantly apparent is the dominance of the iambic $s 4+s 6$ pattern in the Thebes extract, while in the BelleDame extract, no one pattern can be said to dominate. The $s 3+s 5$ and s5only patterns are substantially more common in the BelleDame extract, while the $s 3+s 6$ and s6only patterns are disfavoured in both extracts. The dominance of the iambic pattern in Thebes, I argue, cannot be a coincidence, and thus shows a deliberate attempt by the poet to create an iambic rhythm. In the BelleDame text, on the other hand, it is not clear that an attempt at rhythmic organization has been made. Dating from opposite ends of the chronological period in question, we will see in the next section that the patterns observed in these two extracts are typical of a wider evolution. 


\subsubsection{Chronology}

Using the base corpus, figures 2 and 3 plot the frequency of the six patterns under investigation against time. For ease of reading, I have divided the six patterns into two separate plots. The data from which the charts are generated is provided in the Appendix, and these tables also show the text corresponding to each time period.

Figure 2 : Chronological evolution of the three most frequent patterns in the Base sub-corpus. (Regression: $s 4+s 6 \mathrm{r}=-0.58 ; s 3+s 5 \mathrm{r}=0.73 ;$ s5only $\mathrm{r}=0.68$ )

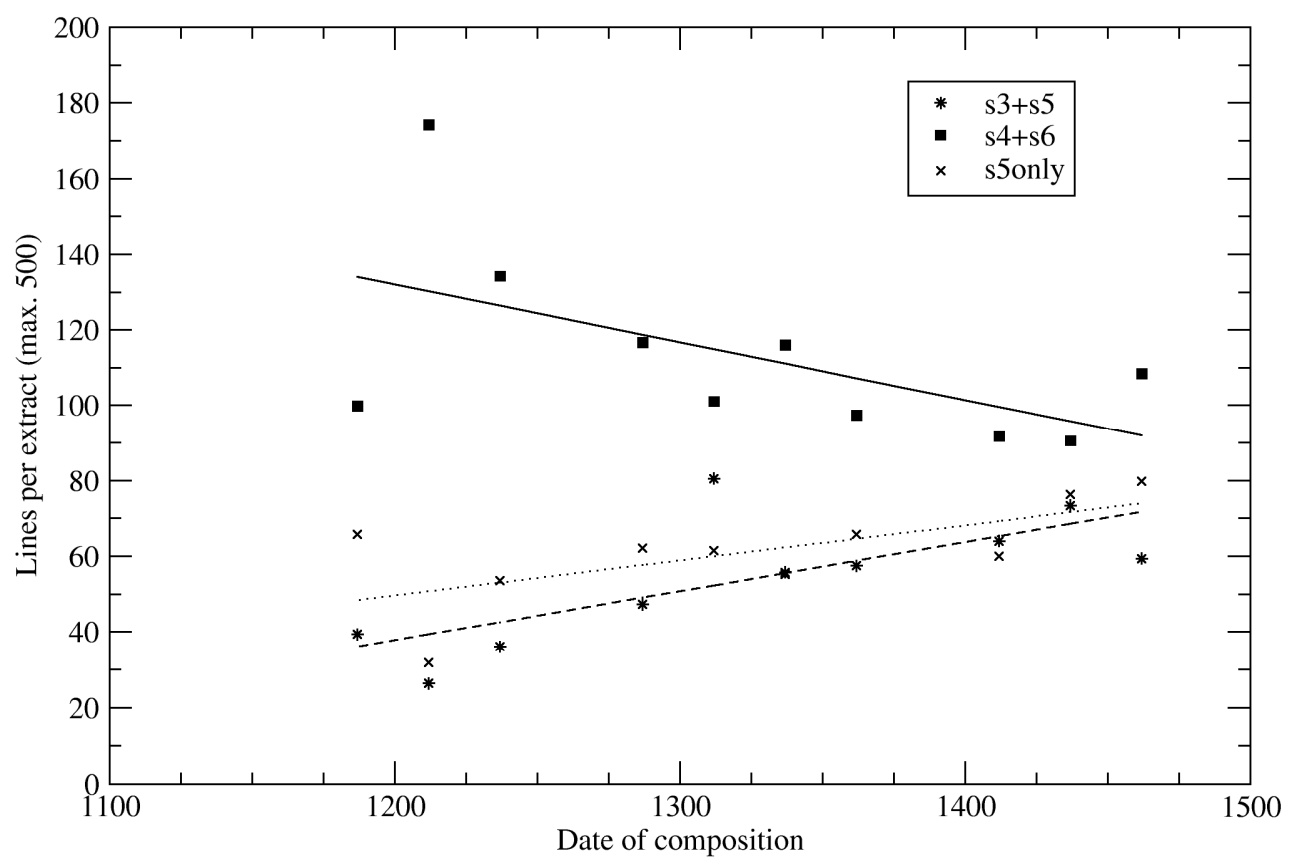


Figure 3: Chronological evolution of the three least frequent patterns in the Base sub-corpus. (Regression: $s 3+s 6 \mathrm{r}=-0.15 ;$ s4only $\mathrm{r}=-0.48 ;$ s6only $\mathrm{r}=0.05)$

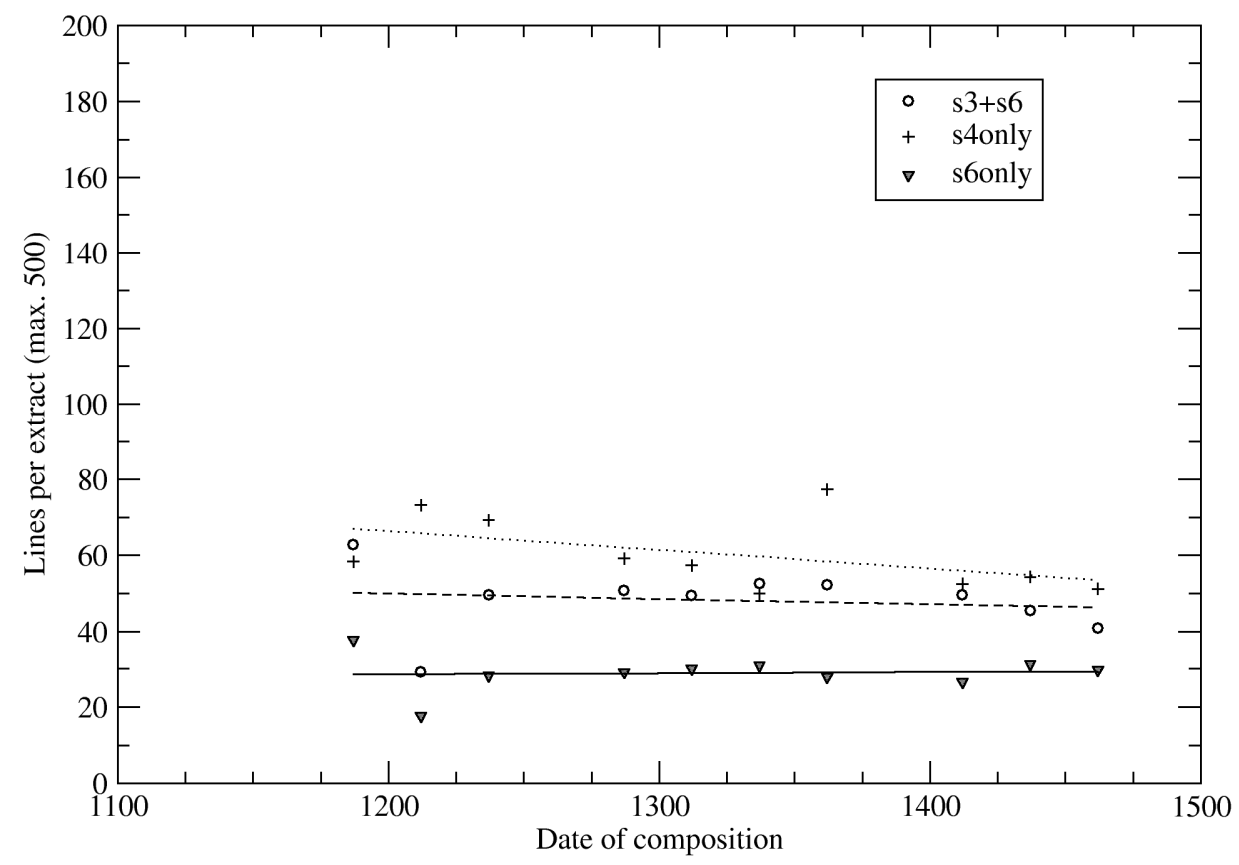

Figure 2 demonstrates a clear trend among the three most common rhythmic patterns in the Base subcorpus. The $s 4+s 6$ pattern is clearly the most common in late $\mathrm{C} 12$ and early $\mathrm{C} 13$ texts, but in the latter half of $\mathrm{C} 12$ the frequency of the competing $s 3+s 5$ and $s 5$ patterns increases. By $\mathrm{C} 15$, it is not the case that a particular rhythmic pattern could be said to dominate, although the iambic $s 4+s 6$ pattern remains most common. There is a clear chronological evolution from texts of the Thebes type to texts of the BelleDame type. Figure 3 demonstrates no particular chronological trend among the three least common patterns, and these will be discounted from subsequent analysis.

To extend the chronological range of Figure 2, the texts from the Early sub-corpus can be plotted together with the Base sub-corpus : ${ }^{11}$ 
Figure 4: Chronological evolution of the three most frequent patterns in the Early and Base sub-corpora. (Regression: $s 4+s 6 \mathrm{r}=-0.65 ; s 3+s 5 \mathrm{r}=0.85 ; s 5$ only $\mathrm{r}=0.7$ )

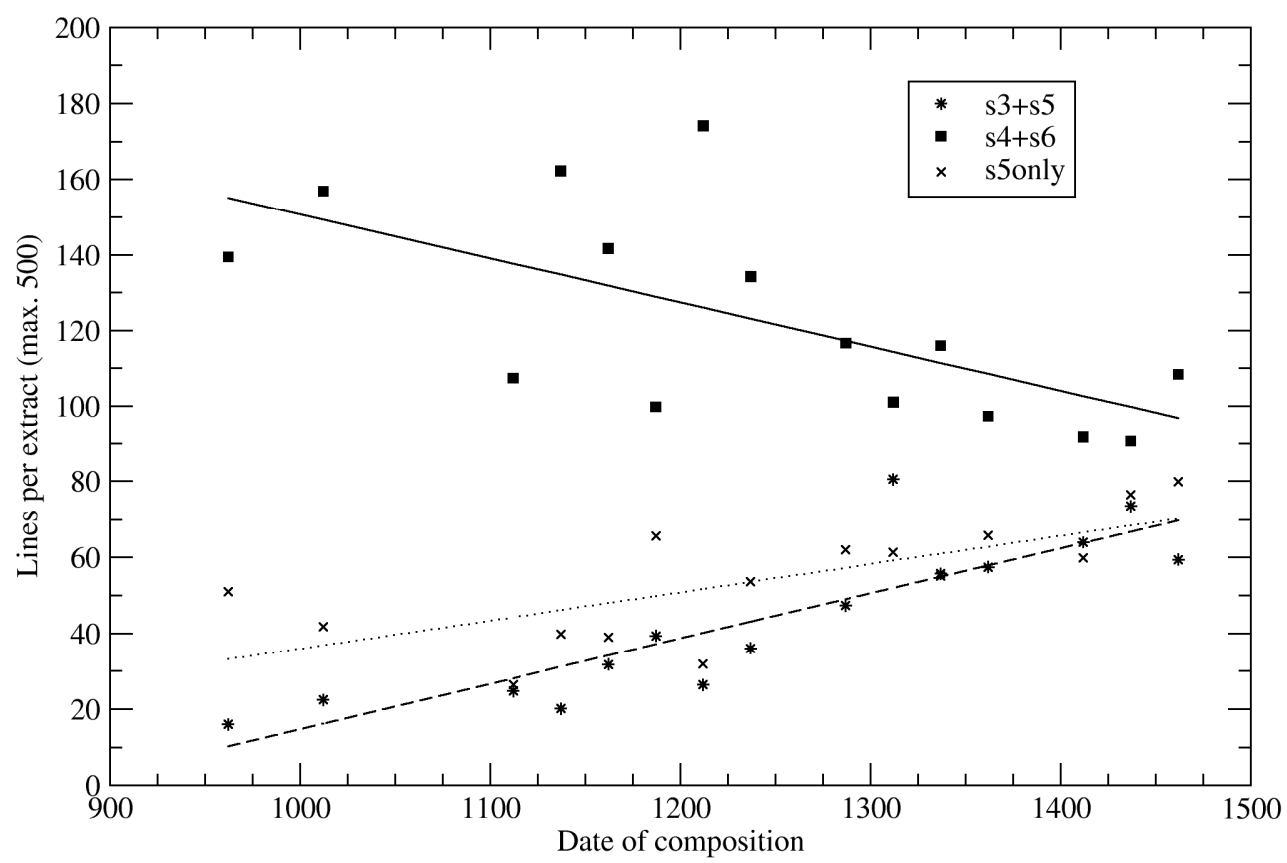

The trends seen in Figure 2 are even more pronounced in Figure 4 where pre-1175 texts are included. In particular, the $s 4+s 6$ pattern is by far the dominant rhythmic pattern in the early texts. Indeed, the $s 4+s 6$ pattern is at least twice as frequent as both the $s 5$ only and the $s 3+s 5$ patterns in every text before 1175 (see Appendix, Tables 2 and 3 for figures).

Do these results show a conscious change in the use of rhythm in verse ? A possible interpretation of the growth of the $s 3+s 5$ and $s 5$ patterns could be that poets chose to vary the rhythms of their lines by using more rhythmic patterns based on a stressed fifth syllable. More striking than the growth of the fifth syllable patterns is the general convergence effect attested by $\mathrm{C} 15$ : all formerly disfavoured patterns become more frequent and all formerly favoured patterns become less frequent. This to me is indicative of a loss of rhythmic organization and the emergence of a purely syllabic verse, rather than simply a change in favoured patterns. The fact that some patterns remain more common than others even by $\mathrm{C} 15$ can probably be explained by properties of the language as a whole, and I would predict a C15 prose text divided into eight-syllable 'pseudo-verses' to show very similar rhythmic patterns to verse texts of the same period.

To summarize, I argue that early French verse was rhythmically iambic, that it ceased to show any rhythmic organization by $\mathrm{C} 15$, and that while variation between texts and a limited corpus makes it hard to date the change precisely, non-iambic texts are attested from the end of $\mathrm{C} 12$ and strongly iambic texts ceased to be common after mid-C13.

\subsubsection{Narrative and theatre}

The Theatre sub-corpus allows us to compare the rhythmic patterns attested in the narrative texts of the Base sub-corpus with those of theatrical texts. Figure 5 shows the results from the Theatre sub-corpus alongside the narrative texts shown in Figure 2. 
Figure 5: Chronological evolution of the three most frequent patterns in the Base and Text Type subcorpora, narrative (left) vs. theatre (right). (Regression (narrative): $s 4+s 6 \mathrm{r}=-0.58 ; s 3+s 5 \mathrm{r}=0.73 ;$ s 5 only $\mathrm{r}=0.68$. Regression (theatre): $s 4+s 6 \mathrm{r}=-0.41 ; s 5$ only $\mathrm{r}=0.57 ; s 3+s 5 \mathrm{r}=0.6$ )

Narrative

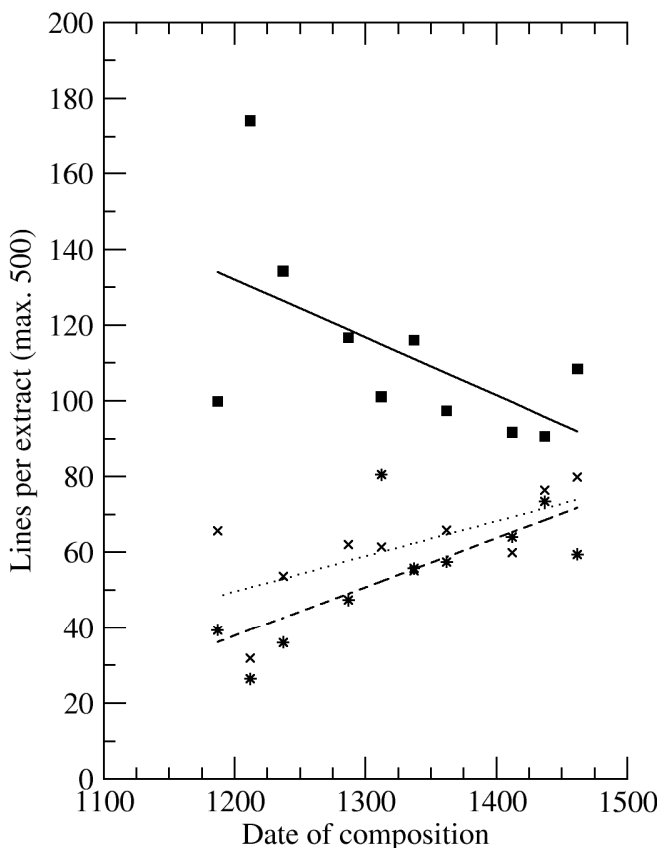

Theatre

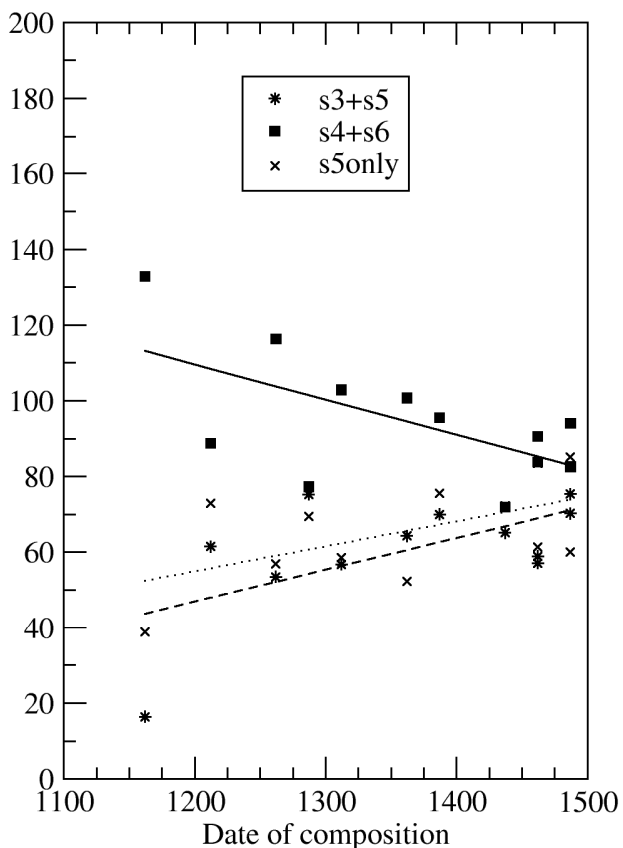

Figure 5 confirms the findings from $\$ 3.2 .2$, showing the same convergence over time of the different rhythmic patterns. The lower values of the correlation coefficient for the theatrical texts, however, show that the trend is not so robustly attested. Indeed, aside from the earliest text (Adam), few theatrical texts show strong iambic organization. Consider the $s 3+s 5$ pattern : no theatrical text besides Adam shows this pattern in fewer than 50 lines per extract, while all of the three earliest narrative texts (Charrette, Coinci and RoseMeun) do. Furthermore, no narrative text shows the $s 4+s 6$ pattern in fewer than 90 lines per extract, while five of the theatrical texts do so (Nicolas, Feuillee, TroisGalans, Pathelin, PassMich). From this observation, I tentatively suggest that rhythmic organization in theatrical texts is lost more rapidly than in narrative texts. It is unfortunate that very few theatrical texts exist from before $\mathrm{C} 13$, as the data from Adam suggest that early theatrical texts may have shown some iambic organization. However, results presented by Guthrie (1987) offer some support to these findings. He compares narrative texts with lyric texts, and shows that rhythmic change in lyric texts proceeds more rapidly than in narratives. Combining the two findings, it appears that narrative texts may be rhythmically conservative. If this is the case, and it merits further investigation, this suggests that rhythmic organization of octosyllabic verse may have declined substantially even as early as late C12.

\section{Conclusion}

I have shown in section three that over the course of the period 1000-1500, the rhythm of octosyllabic verse evolves from strongly iambic beginnings to a stage of such rhythmic diversity that it seems inappropriate to speak of rhythmic organization. Chronologically, the locus of this change (in narrative at least) is $\mathrm{C} 13$; the extreme variability between texts makes it difficult to isolate with any greater degree of accuracy. The finding that both theatrical texts and (thanks to Guthrie 1987) lyric texts show this evolution occurring at an earlier date leads me to speculate that narrative texts may be conservative, and 
that if the change in versification patterns is driven by linguistic change, the linguistic change may date from mid to late $\mathrm{C} 12$ rather than early $\mathrm{C} 13$.

\subsection{Linguistic change?}

But can the loss of rhythmic organization be attributed to a linguistic change ? It is not possible to state this as fact, but the phenomenon of 'stress deafness' is an important possible link. Following the theory outlined in Dupoux and Peperkamp (2002), stress deafness in modern French is a consequence of speakers failing to acquire the ability to encode stress in the lexicon, which is in turn caused by the nonlexical nature of group stress in French. A predictable pattern of stressed and unstressed syllables in verse seems unlikely to be salient to speakers for whom the stressed vs. unstressed syllable distinction is not phonologically relevant; hence, verse ceases to make use of rhythmic organization. It does not become impossible to write French verse which would be recited with an iambic rhythm - Duffell and Billy (2004) show that the French verse of the C14 English writer John Gower is highly iambic - but such an exercise becomes a "regularization of the imperceptible" (2004: 396).

If stress deafness provides us with a principled reason to believe that loss of rhythmic organization is linked to prosodic change, morpho-phonological changes occurring in C11 and C12 support the proposed chronology. To take one example, loss of enclisis in French has been argued to be related to changing prosodic patterns (e.g. Pope 1952 : $§ 602$, Kukenheim 1971; for a formal analysis of object clitics only see Jacobs 1993). In early texts, such as the C11 Vie de Saint Alexis, object pronouns appear enclitic on a number of elements:

$$
\begin{array}{ll}
\text { (6) } & \text { net poi aviser } \\
\text { (7) } & \text { Se jot soüsse } \\
(8) & \text { Sit guarderai } \\
\text { (9) } & \text { Si'st ampairet }
\end{array}
$$

(negative + ocl; Alexis 1. 395)

(subject pronoun + ocl; Alexis 1. 486)

(adverb + ocl; Alexis 1. 152)

$\left(\right.$ adverb + auxiliary est; Alexis 1. 10) ${ }^{12}$

In examples (6-8), the object clitic te appears enclitic on a variety of elements, while in (9) auxiliary est is enclitic. The host word is argued to bear a secondary stress, alongside the primary stress on the verb. Over the course of the Old French period, enclisis of this kind was lost, remaining only in the lexicalized preposition plus article forms (e.g. $a u, d u, a u x, d e s$ ). Pope (1952: §602) is vague about the precise chronology of the change, but examples such as (9) and enclisis to polysyllables are hardly attested by late $\mathrm{C} 12$, while forms such as (6) and (7) remain into C13. The chronology of the change is thus broadly similar to that suggested in $\S 3.2 .2$, which sees rhythmic organization lost by mid-C13.

\subsection{Future work}

There remains much scope for future work. In particular, it will be crucial to compare the rhythm of verse texts with the rhythm of prose-derived 'pseudo-verse', in order to test the claim that there is no conscious organization of stress in verse post-C13. Furthermore, the claim that stress deafness emerges in C13 should be tested by studying the language of the corpus extracts for conformity to Dupoux and Peperkamp's (2002) typology of the expected properties of languages displaying stress deafness effects. Finally, if it is the case that group stress emerges in late C12, a study of the morphological and syntactic correlates of this prosodic change may shed new light on the relationship between syntax and prosody. 


\section{Appendix: Data Tables}

Table 2: Pre-1150 texts, lines out of 500 matching each pattern (normalized, weighted ${ }^{13}$ )

\begin{tabular}{|c|c|c|c|c|c|c|c|}
\hline \multirow{2}{*}{ Extract } & \multirow{2}{*}{$\begin{array}{l}\text { Approx. date of } \\
\text { composition }\end{array}$} & \multicolumn{6}{|l|}{ Patterns } \\
\hline & & $s 4+s 6$ & s4only & s5only & s6only & $s 3+s 5$ & $s 3+s 6$ \\
\hline Leger & c. 1000 & 139 & 68 & 51 & 26 & 16 & 19 \\
\hline Clermont & c. 1000 & 157 & 86 & 42 & 16 & 22 & 18 \\
\hline Brendan & c. $1106-1121$ & 107 & 38 & 26 & 20 & 25 & 48 \\
\hline Gormont & c. $1120-1130$ & 162 & 81 & 40 & 18 & 20 & 19 \\
\hline Thebes & c. $1150-1160$ & 142 & 69 & 39 & 26 & 32 & 48 \\
\hline
\end{tabular}

Table 3: Base corpus, lines out of 500 matching each pattern (normalized, weighted)

\begin{tabular}{|c|c|c|c|c|c|c|c|}
\hline \multirow{2}{*}{ Extract } & \multirow{2}{*}{$\begin{array}{l}\text { Period of } \\
\text { composition }\end{array}$} & \multicolumn{6}{|l|}{ Patterns } \\
\hline & & $s 4+s 6$ & s4only & s5only & s6only & $s 3+s 5$ & $s 3+s 6$ \\
\hline Charrette & 1175-1199 & 100 & 58 & 66 & 38 & 39 & 63 \\
\hline Coinci & $1200-1224$ & 174 & 73 & 32 & 18 & 26 & 29 \\
\hline PassJong & $1225-1249$ & 134 & 69 & 54 & 28 & 36 & 50 \\
\hline RoseMeun & $1275-1299$ & 117 & 59 & 62 & 29 & 47 & 51 \\
\hline Anjou & $1300-1324$ & 101 & 57 & 61 & 30 & 81 & 49 \\
\hline LiberFort & $1325-1349$ & 116 & 50 & 55 & 31 & 56 & 53 \\
\hline VoirDit & $1350-1374$ & 97 & 77 & 66 & 28 & 58 & 52 \\
\hline Fortune & $1400-1424$ & 92 & 53 & 60 & 27 & 64 & 50 \\
\hline BelleDame & $1425-1449$ & 91 & 54 & 76 & 31 & 73 & 45 \\
\hline Testament & $1450-1475$ & 108 & 51 & 80 & 30 & 59 & 41 \\
\hline
\end{tabular}


Table 4: Theatrical corpus, lines out of 500 matching three most common patterns (normalized, weighted)

\begin{tabular}{|l|l|c|c|c|}
\hline \multirow{2}{*}{ Extract } & \multirow{2}{*}{$\begin{array}{l}\text { Period of } \\
\text { composition }\end{array}$} & \multicolumn{2}{l}{ Patterns } \\
\cline { 3 - 5 } & & $s 4+s 6$ & $s 5$ only & $s 3+s 5$ \\
\hline Adam & $1150-1174$ & 133 & 39 & 16 \\
\hline Nicolas & $1200-1224$ & 89 & 73 & 62 \\
\hline Theophile & $1250-1274$ & 116 & 57 & 54 \\
\hline Feuillee & $1275-1299$ & 77 & 69 & 75 \\
\hline Palatinus & $1300-1324$ & 103 & 59 & 57 \\
\hline NotreDame & $1350-1374$ & 101 & 52 & 64 \\
\hline Griseldis & $1375-1399$ & 96 & 76 & 70 \\
\hline TroisGalans & $1425-1449$ & 72 & 72 & 65 \\
\hline PassGreb & $1450-1474$ & 91 & 84 & 57 \\
\hline Pathelin & $1450-1474$ & 84 & 61 & 59 \\
\hline
\end{tabular}

\section{References}

\section{$\underline{\text { Corpus }}$}

Adam (c1146-74, Theatre) Noomen, W. (ed.) (1971). Le jeu d'Adam = Ordo representacionis Ade. Paris: Champion. Anjou (1316, Base) Roques, M. (ed.) (1931). Le roman du comte d'Anjou, by Jehan Maillart. Paris: Champion.

BelleDame (1424, Base) La Belle Dame sans mercy, by Alain Chartier. In Laidlaw, J. C. (ed.) (1976). The Poetical Works of Alain Chartier. Cambridge: Cambridge University Press.

Brendan (c1106-1121, Early) Short, I. and B. Merrilees (eds) (1979). The Anglo-Norman Voyage of St. Brendan, by Benedeit. Manchester: Manchester University Press

Charrette (c1179, Base) Le Chevalier de la charrette, by Chrétien de Troyes. In Roques, M. (ed.) (1952-72). Romans: édités d'après la copie de Guiot, 6 vols. Paris: Champion.

Clermont (c1000, Early) Avalle, D. S. (ed.) (1962). Cultura e lingua francese delle origini nella Passion di Clermont-Ferrand. Milan, Naples: Ricciardi.

Coinci (1218-36, Base) Koenig, V. F. (ed.) (1955-70). Les miracles de Nostre Dame par Gautier de Coinci, 4 vols. Geneva: Droz.

Feuillee (1276, Theatre) Langlois, E. (ed.) (1951). Le Jeu de la feuillée, by Adam le Bossu, trouvère artésien du XIIIe siècle. Paris: Champion.

Fortune (1403, Base) Solente, S. (ed.) (1959-66). Le livre de la mutacion de fortune, by Christine de Pisan, 4 vols. Paris: A. \& J. Picard.

Gormont (c1120-30, Early) Bayot, A. (ed.) (1931). Gormont et Isembart : fragment de chanson de geste du XIIe siècle, 3rd ed. Paris: Champion.

Griseldis (1395, Theatre) Roques, M. (ed.) (1957). L'estoire de Griseldis, en rimes et par personnages, 1395. Geneva: Minard; Paris: Droz.

Holofernes (1480-90, RelTh) Runnells, G. A. (ed.) (1995). Le mystère de Judith et Holofernés, attr. to Jean Molinet. Geneva: Droz. 
LiberFort (1346, Base) Grigsby, J. L. (ed.) (1967). The Middle French 'Liber Fortunce'. Berkeley: University of California Press.

Leger (c.1000, Early) Linskill, J. (ed.) (1937). Saint Léger : Étude de la langue du manuscrit de Clermont-Ferrand, suivie d'une édition critique. Paris: Droz.

Nicolas (c1200, Theatre) Henry, A. (ed.) (1965). Le jeu de saint Nicolas de Jehan Bodel, 2nd ed. Brussels: PUB.

NotreDame (1339-82, Theatre) Paris, G. and U. Robert (eds) (1876-93). Miracles de Nostre Dame par personnages, 8 vols. Paris: Firmin Didot.

Palatinus (c1300-15, Theatre) Frank, G. (ed.) 1970. La Passion du Palatinus: mystère du XIVe siècle. Paris: Champion.

PassGreb (c1450, Theatre) Jodogne, O. (ed.) (1965-83). Le Mystère de la Passion, by Arnoul Gréban, 2 vols. Brussels: Académie royale de Belgique.

PassJong (1243, Base) Perry, A. (ed.) (1981). La passion des jongleurs. Paris: Beauchesne.

PassMich (1486, Theatre) Jodogne, O. (ed.) (1959). Le mystère de la Passion (Angers 1486), by Jean Michel. Gembloux: Duculot.

Pathelin (1470-5, Theatre) Dufournet, J. (ed. and trans.) (1986). La farce de maître Pierre Pathelin. Paris: Flammarion.

RoseMeun (1275-80, Base) Lecoy, F. (ed.) (1966-70). Le roman de la rose, by Guillaume de Lorris and Jean de Meun, 3 vols. Paris: Champion.

Testament (1461-2, Base) Rychner, J. and A. Henry (eds) (1974). Le Testment Villon, 2 vols. Geneva: Droz.

Thebes (1150-60, Early) Raynaud de Lage, G. (ed.) (1966-8). Le Roman de Thèbes, 2 vols. Paris: Champion.

Theophile (c1249-78, Theatre) Frank, G. (ed.) (1949). Le miracle de Théophile, by Rutebeuf. Paris: Champion.

TroisGalans (1445, Theatre) Trois galans, le monde qu'on faict paistre et Ordre. In Picot, E. (ed.) (1902-12). Recueil général des sotties, 3 vols. Paris: Firmin Didot.

VoirDit (1363-5, Base) Imbs, P. (ed. and trans.) (1999). Le livre du voir dit (Le dit véridique), by Guillaume de Machaut. [Paris]: Livre de Poche.

Secondary sources:

Banniard, M. (1998). Le Problème de l'accent en français: Remarques sur son origine et sur son évolution. In J. C. Faucon, A. Labbé and D. Quéruel (eds) Miscellanea mediaevalia: Mèlanges offerts à Philippe Ménard. Paris: Champion, 65-73.

Duffell, M. J. and D. Billy (2004). From Decasyllable to Pentameter: Gower's Contribution to English Verse. Chaucer Review, 38, 383-400.

Dupoux, E., C. Pallier, N. Sebastian and J. Mehler (1997). A destressing "deafness" in French? Journal of Memory and Language, 36, 406-21.

Dupoux, E., S. Peperkamp, and N. Sebastián-Gallés (2001). A robust method to study stress 'deafness'. Journal of the Acoustical Society of America, 110, 1606-1618.

Dupoux, E. and S. Peperkamp (2002). Fossil markers of language development: phonological "deafnesses" in adult speech processing, in B. Laks and J. Durand (eds) Phonetics, Phonology, and Cognition. Oxford: Oxford University Press, $168-90$.

Dupoux, E., N. Sebastián-Gallés, E. Navarrete and S. Peperkamp (2008). Persistent stress 'deafness': The case of French learners of Spanish. Cognition, 106, 682-706.

Guthrie, S. R. (1987). Machaut and the Octosyllabe. Studies in the Literary Imagination, 20, 55-75.

Halle, M. and S. J. Keyser (1971). English Stress: Its Form, its Growth, and its Role in Verse. New York: Harper and Row.

Jacobs, H. (1993). The Phonology of Enclisis and Proclisis in Gallo-Romance and Old French. In W. J. Ashby et al. (eds) Linguistic Perspectives on the Romance Languages. Amsterdam: John Benjamins, 149-64. 
Klausenburger, J. (1970). French Prosodics and Phonotactics: An Historical Typology, Beiheifte zur Zeitschrift für Romanische Philologie, 124. Tübingen: Max Niemeyer Verlag.

Kukenheim, L. (1971). Rôle de la prosodie dans l'histoire de la langue française. In I. Cluzel and F. Pirot (eds) Mélanges de philologie romane dédiés à la mémoire de Jean Boutière (1899-1967), 2 vols. Liège: Soledi, vol. 1: $317-331$

Lacheret-Dujour, A. and F. Beaugendre (1999). La prosodie du français. Paris: CNRS.

Le Mée, K. W. (1978). A Metrical Study of Five Lais of Marie de France. The Hague: Mouton.

Lote, G. (1949-96). Histoire du vers français, 9 vols. Paris: Boivin [1-3]; Aix-en-Provence: Université de Provence [4-9].

Melander, J. (1928). Etude sur l'ancienne abréviation des pronoms personnels régimes dans les langues romanes. Uppsala: Almqvist \& Wiksells.

Noyer, R. (2002). Generative Metrics and Old French Octosyllabic Verse. Language Variation and Change, 14, 11971.

Pensom, R. (2000). Accent and Metre in French: A Theory of the Relation between Linguistic Accent and Metrical Practice in French, 1100-1900. Bern: Peter Lang.

Peperkamp, S. (2004). Lexical Exceptions in Stress Systems: Arguments from Early Language Acquisition and Adult Speech Perception. Language, 80, 98-126.

Peperkamp, S. and E. Dupoux (2002). A Typological Study of Stress 'Deafness'. In C. Gussenhoven and S. Warner (eds) Laboratory Phonology VII. Berlin: Mouton de Gruyter, 203-40.

Pope, M. K. (1952). From Latin to Modern French with Especial Consideration of Anglo-Norman, 2nd ed. Manchester: Manchester University Press.

\footnotetext{
${ }^{1}$ This paper presents research conducted as part of a doctoral project at the University of Cambridge funded by the UK Arts and Humanities Research Council (AHRC). The author would like to thank Wendy Ayres-Bennett and an anonymous reviewer for many helpful comments in the preparation of this paper.

${ }^{2}$ Stressed syllables are underlined throughout.

${ }^{3}$ There are a few exceptions, notably object pronouns, e.g. MĒUM $>$ me /mə/ when proclitic; > Early OFr. mei /mej/ when not.

${ }^{4}$ A good summary may be found in Lacheret-Dujour and Beaugendre (1999: part II, ch. 3)

${ }^{5}$ Were this not the case, regular sound change would have given */lablə'fi אə/ in Old French.

${ }^{6}$ Conventionally, the octosyllable is not thought to have a cæsura.

${ }^{7}$ Although, as schwa is never directly marked in orthography, there is some debate as to which orthographic $<\mathrm{e}>\mathrm{s}$ are schwa and which are full vowels. Basing myself mainly on traditional manuals such as Pope (1952), I have assumed schwa to be represented by (i) post-tonic $<\mathrm{e}\rangle$, (ii) intertonic $\langle\mathrm{e}\rangle$ in open syllables, (iii) initial $<\mathrm{e}\rangle$ in an open syllables and (iv) $<\mathrm{e}>$ in monosyllabic function words showing an historically unstressed phonological evolution (e.g. le, de, me, te, se, que, etc.).

${ }^{8}$ The prominence rule is not dissimilar from the definition of a stress maximum in the Generative Metrics tradition, first defined by Halle and Keyser (1971). The intuition too is similar : in accentual verse, these syllables are those stressed syllables which are most salient from a metrical point of view.

9 The data presented in this paper are drawn from a wider corpus, the analysis of which remains ongoing. In particular, the wider corpus was designed to contains from Anglo-Norman, Northern and Eastern dialects, with a view to investigate whether rhythmic change proceeded at the same rate in each area. Preliminary investigations have as yet yielded no suggestion of a difference according to dialect. As dialect does not seem to be an important factor in the change under consideration, I feel it is justified to include three non-central texts in the Theatrical sub-corpus : Adam (Anglo-Norman), Nicolas (Picard) and Feuillee (Picard).
} 
${ }^{10}$ It is possible that the stress in the two initial positions needs to be considered separately from the rest of the line in any case. The well-attested phenomenon of first-foot reversal in English iambic verse, in which the first iamb only (weak-strong) may become a trochee (strong-weak) without violating the constraints of the meter, suggests that stress in these two positions is treated differently from in the rest of the line. Moreover, a preliminary study of the French data suggests that the clearly attested preference for iambic rhythm in early texts does not extend to a preference for second syllable over first syllable stress. Consideration of the issue is thus beyond the scope of this paper.

${ }^{11}$ This introduces dialectal variation, but preliminary results suggest this is not an important factor (see also note 9 above).

${ }^{12}$ Examples from Melander (1928: 24) and Pope (1952: §602).

${ }^{13}$ As extracts are approximately, but not exactly, 500 lines, the figures are normalized to an exact length of 500 lines in order to make them comparable. The method of weighting is described in $\$ 3.2$. 